\title{
Reproductive ecology and behavior of Eleutherodactylus aureolineatus (Anura, Brachycephalidae) in the canopy of the Upper Amazon Basin, Ecuador
}

\author{
Shawn F. McCracken ${ }^{1}$ and Michael R. J. Forstner \\ Department of Biology, Texas State University, 601 University Drive, San Marcos, Texas, 78666, USA. E-mail: \\ smccracken@txstate.edu. \\ 1 TADPOLE Organization, 2214 South First Street, Austin, Texas, 78704, USA.
}

\begin{abstract}
Reproductive ecology and behavior of Eleutherodactylus aureolineatus (Anura, Brachycephalidae) in the canopy of the Upper Amazon Basin, Ecuador. Exploration and investigation of the anuran fauna in the canopies of the Upper Amazon Basin has led to the recent discoveries of new species of the genus Eleutherodactylus utilizing the microhabitat within bromeliads. Detailed information on the ecology and natural history of these communities are scarce due, in part, to the difficulty of accessing their habitat. New sampling methods for rainforest canopies have allowed for the collection and observation of the herpetofauna utilizing this habitat. Sexual size dimorphism in Eleutherodactylus aureolineatus, confirms placement in the E. unistrigatus species group and E. lacrimosus assemblage. The described microhabitat, vocalization characteristics, reproductive behavior and egg deposition of $E$. aureolineatus provides significant ecological background on this poorly documented group of frogs and their important "wetlands in the sky". The data and observations herein contribute to the overall understanding of the characters and ecological factors which define the E. lacrimosus assemblage.
\end{abstract}

\section{Resumen}

Ecología y comportamiento reproductivo de Eleutherodactylus aureolineatus (Anura, Brachycephalidae) del dosel de la cuenca del Amazonas Superior, Ecuador. La exploración y la investigación de la fauna de anuros en el estrato del dosel de la cuenca del Amazonas Superior ha llevado a descubrimientos recientes de nuevas especies del genero Eleutherodactylus que utilizan el interior de las bromelidas como micro-hábitat. La información detallada en la ecología y la historia natural de estas comunidades es escasa debido en parte a la dificultad de acceso de su hábitat. Nuevos métodos de muestreo para doseles de selvas pluviales han tomado en cuenta

Received 25 September 2006.

Accepted 30 November 2006.

Distributed December 2006. 
la colecta y la observación de la herpetofauna que utiliza este hábitat. El dimorfismo sexual de tamaño en Eleutherodactylus aureolineatus confirma su posición dentro del grupo de especies de E. unistrigatus y la colección de E. lacrimosus. La descripción del micro-hábitat, características de vocalización, comportamiento reproductivo y el sitio de deposición de huevo de E. aureolineatus provee antecedentes ecológicos importantes para este grupo de ranas pobremente documentadas y sus importantes “pantanos en el cielo”. Los datos y las observaciones que aquí se presentan, contribuyen a la comprensión general de los caracteres y los factores ecológicos que definen la colección de E. lacrimosus.

Keywords: Anura, Brachycephalidae, Eleutherodactylus aureolineatus, Eleutherodactylus lacrimosus, Eleutherodactylus unistrigatus, advertisement call, reproductive behavior, canopy sampling, sexual size dimorphism, Ecuador.

\section{Introduction}

Eleutherodactylus aureolineatus (Figure 1) was recently described by Guayasamin et al. (2006) from Provincia de Sucumbios and Provinicia de Orellana of northeastern Ecuador, and Departamento de Loreto of northeastern Peru at elevations less than 350 m.a.s.l. Eleutherodactylus aureolineatus is primarily an inhabitant of large tank bromeliads in the upper strata of the rainforest canopy (less than $50 \mathrm{~m}$ vertical height). It is a member of a phenetic subgroup called the Eleutherodactylus lacrimosus assemblage of the greater Eleutherodactylus unistrigatus species group applied by Lynch and Duellman (1980, 1997) (Heyer and Hardy 1991, Guayasamin et al. 2006). The assignment was loosely based on morphological characters and preference of bromeliad habitat. Herein we specifically examine those characters most relevant to the assignment of $E$. aureolineatus to the E. unistrigatus group and E. lacrimosus assemblage. Adult type specimens of E. aureolineatus were examined for sexual size dimorphism (SSD) in snout-to-vent length (SVL), head width (HW), tibia length (TL) and tympanum diameter (TD). The E. lacrimosus assemblage as a whole is not well known. Habitat, advertisement call, reproductive behavior and egg deposition for E. aureoli- neatus are reported herein. We intend to provide both additional data on this species and contribute to the knowledge of the E. lacrimosus assemblage, while emphasizing the importance

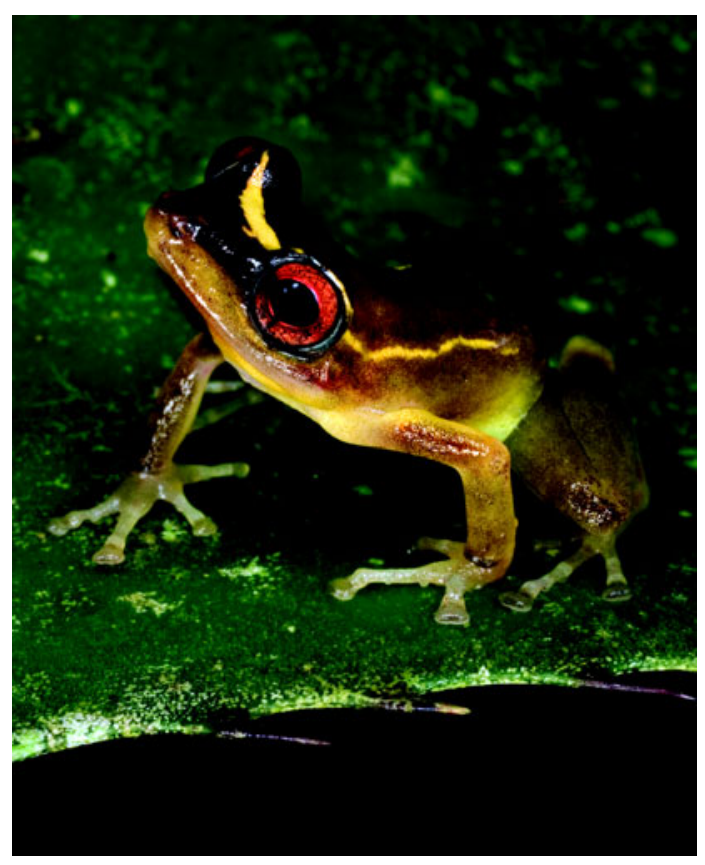

Figure 1 - Eleutherodactylus aureolineatus, male, voucher ID - TCWC 90335. Tiputini Biodiversity Station, Provincia de Orellana, Ecuador. Photo by Bejat McCracken, taken on August 16, 2004. 
of canopy surveys and bromeliad patch sampling techniques.

\section{Materials and Methods}

Raw morphometric data were used for the adult type specimens $(n=16)$ in Guayasamin et al. (2006) (Appendix I). Specimens examined were from the herpetological collections at Museo de Zoología of the Universidad Católica del Ecuador, Quito (QCAZ); Universidad San Francisco de Quito, Quito (DFCH-USFQ); Natural History Museum of The University of Kansas, Lawrence (KU); and The Natural History Collection at Texas A\&M University Texas Cooperative Wildlife Collection, College Station (TCWC). Data for type specimens (TCWC 90334-90342) collected by the author were taken during bromeliad patch sampling surveys at the Tiputini Biodiversity Station (TBS) - Universidad San Francisco de Quito ( $\left.0^{\circ} 38^{\prime} 19^{\prime} \mathrm{S}, 76^{\circ} 08^{\prime} 57^{\prime \prime} \mathrm{W}\right)$ in the eastern lowlands of Amazonian Ecuador between June and August 2004.

Single-rope climbing technique (SRT) was used to access canopy bromeliads in two trees from each of four terrestrial quadrat strip plots. Five bromeliads $(n=40)$ were removed from each tree and placed in large plastic bags to be lowered to the forest floor and transported to camp. Individual leaves were removed to allow collection of all anurans within a screened enclosure to prevent escape. Vertical height of bromeliads was obtained by attaching a $100 \mathrm{~m}$ reel tape measure to the tree climber's harness and positioning the reel at the base of the tree, height was recorded by a climbing assistant on the ground when the climber was level with the bromeliad being collected. Environmental data were recorded for collection sites and reported herein for occurrences of E. aureolineatus, and include: temperature $\left({ }^{\circ} \mathrm{C}\right)$ at 0 and $1 \mathrm{~m}$ and bromeliad collection site; barometric pressure $(\mathrm{hPa})$ at $1 \mathrm{~m}$ and bromeliad collection site with a Brunton Sherpa; humidity (\% relative humidity) at $1 \mathrm{~m}$ with a sling psychrometer; $\mathrm{pH}$ of water in bromeliad with a Oakton (pHTestr 30) meter; volume (L) of water in bromeliad with graduated cylinder; and diameter at breast height $(\mathrm{DBH})$ of tree to the nearest $1.0 \mathrm{~mm}$. Spatial distribution of sampled trees is represented by altitude (m.a.s.l.) and the distance (m) due north of the Tiputini River using the measurement tool in ArcInfo 9.1 (Figure 2).

Following Guayasamin (2004) and Fuentes and Barrio-Amorós (2004), morphological measurements were taken from preserved specimens to the nearest $0.1 \mathrm{~mm}$. The variables snout-to-vent length (SVL), tibia length (TL) and head width (HW), were used in this analysis of SSD because of greater confidence in the accuracy of measurement (Hayek and Heyer 2005). Historically, morphometric data other than SVL has been transformed or converted to ratios of the measures. Hayek and Heyer (2005) provide significant tests to the contrary and show that these transformations often greatly reduce the observed effect size. Because of a small sample size $(n=16)$ the Mann-Whitney $U$ Test was used for the analyses. Analyses for SSD were performed on SVL, HW, TL, and tympanum diameter (TD) using the raw morphometric data for adult specimens of $E$. aureolineatus with a significance level of á = 0.05 . Statistical analyses were performed with SPSS version 14.0.

One individual (TCWC 90335) was collected on 31 July 2004 and recorded on 8 August 2004. This individual began calling once the bromeliad was sealed in the transport bag, and upon opening the bag a total of 4 individuals were observed within the bromeliad bracts; two adult males (TCWC 90335 and 90338), a gravid adult female (TCWC 90337) and a juvenile female (TCWC 90336). Call recording and observation of reproductive behavior was facilitated by placing the bromeliad in a low tree crotch and covering it in a mosquito net to prevent escape.

Call data was recorded using a Marantz PMD201 portable tape recorder with an Azden SGM-2X shotgun microphone on THAT's 60 


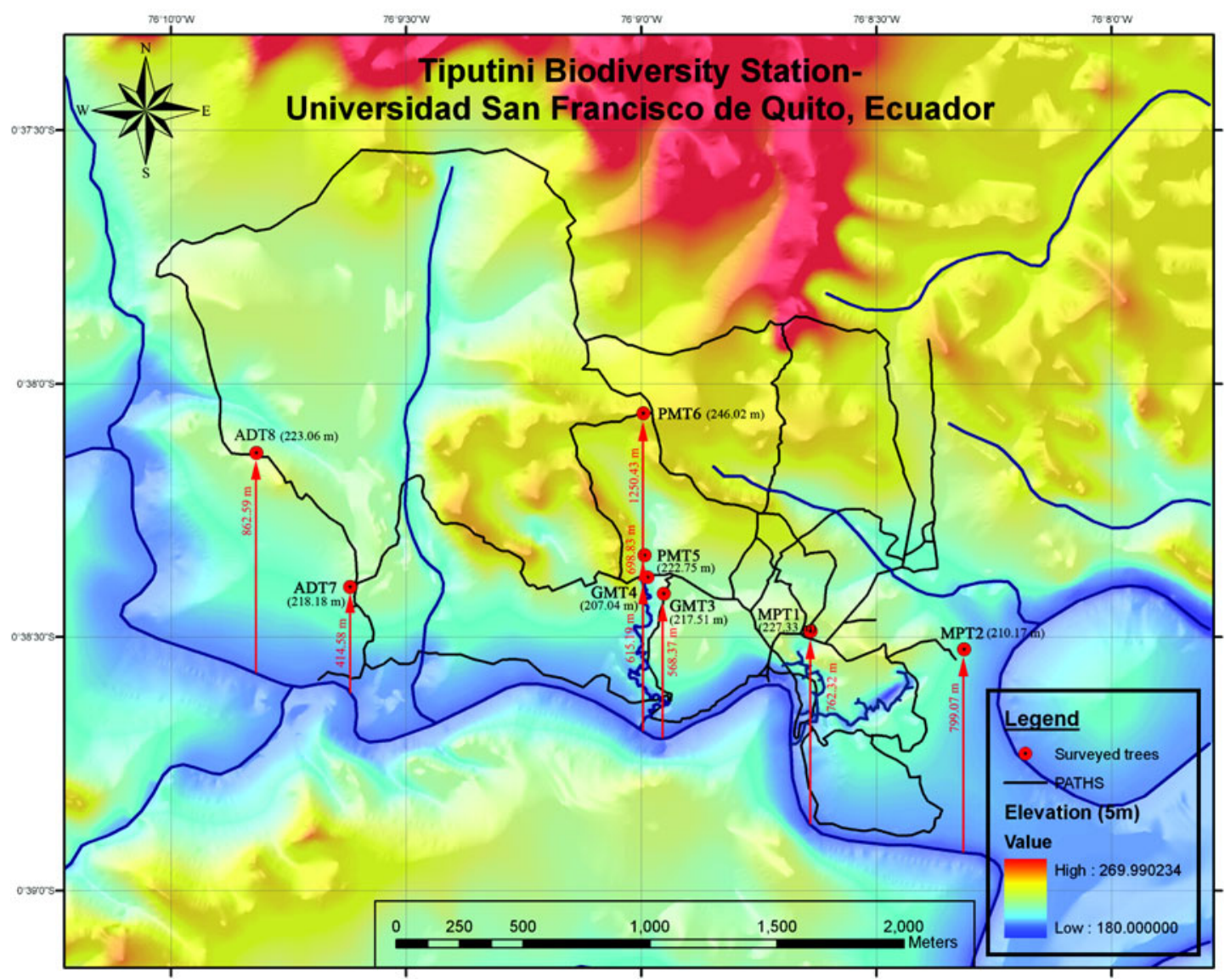

Figure 2 - Map of trees sampled for canopy anurans within bromeliads at the Tiputini Biodiversity Station, Universidad San Francisco de Quito, Ecuador. Tree distances due north of river in red and elevation in black.

minute metal cassette tapes at $0.5 \mathrm{~m}$ from calling individual. Call digitizing and analysis was performed using Raven version 1.3 (Cornell Laboratory of Ornithology 2006). A sampling rate of $44.1 \mathrm{kHz}$ was used to digitize signals at a size of 16 bits. Figure of spectrogram calculated using fast Fourier transform (FFT) with a window size $=512$ samples, window overlap $=$ $50 \%$ and window type $=$ Hann. Call parameters terminology follows Duellman and Trueb (1994).

Eggs were measured immediately following deposition and before preservation using dial calipers to the nearest $0.1 \mathrm{~mm}$. Eight were preserved in $70 \% \mathrm{ETOH}$ and nine were preserved in $10 \%$ formalin.

\section{Results}

\section{Sexual Size Dimorphism}

Females were found to be significantly larger for SVL (Mann-Whitney U, Z = -2.701, $\mathrm{P}=$ 0.007), HW (Mann-Whitney U, Z = -2.489, $\mathrm{P}=$ 0.013 ) and TL (Mann-Whitney $U, Z=-1.960, P$ $=0.050$ ) (Appendix I). No difference between males and females was found for TD (MannWhitney $\mathrm{U}, \mathrm{Z}=-1.439, \mathrm{P}=0.150$ ). 


\section{Habitat}

Eleutherodactylus aureolineatus occurred in four of the 40 sampled bromeliads. These four bromeliads were found in just two of the sampled trees, two in each tree. Both trees are located in primary terra firme forest following a ridgetop (Figure 2). The first tree (PMT5) was identified as Dimorphandra sp.1 of the subfamily Caesalpinioideae in the family Leguminosae and the second (PMT6) could be positively identified only to the family Leguminosae (Ribeiro et al. 1999). All four large tank bromeliads (PMT5B1, PMT5B4, PMT6B1 and PMT6B2) were identified as Aechmea zebrina (Kreft and Köster 2004). Vertical heights and environmental data were collected for bromeliads (Appendix II).

\section{Vocalization}

One adult male (TCWC 90335) called nightly, 31 July 2004 through 14 August 2004, from the collected bromeliad under the mosquito netting. Calling began around 18:00-19:00 h and continued until approximately 01:00 h. The other adult male (TCWC 90338) was never observed calling during this time. On 8 August 2004, the advertisement call of TCWC 90335 was recorded from 21:00-21:30 h at an air temperature of $22.5^{\circ} \mathrm{C}$ and $97 \%$ humidity; 325 calls belonging to 15 call groups with duration of 1771.35 seconds (S) were analyzed. The advertisement call consists of a single note chirp repeated in call groups of $7-52(\bar{x}=21 \pm 11$, $n=15)$ calls, with an interval between call groups of $19.94-242.60(\bar{x}=79.98 \pm 65.30$, $n=14)$ S. Call rate 16.7-40.4 $(\bar{x}=29.7 \pm 5.8$, $n=15$ ) per minute (Figure 3 ). Dominant frequency (=fundamental) 1690.9-4254.8 $(\bar{x}=3078.4 \pm 164.6, n=325)$ Hertz $(\mathrm{Hz})$; notes variable with no frequency modulation to a slight upward modulation. A single harmonic structure present at a frequency of 7616.6$10797.7(\bar{x}=9000.9 \pm 380.5, n=325) \mathrm{Hz}$. Note duration was 15.1-42.0 $(\bar{x}=25.9 \pm 4.6$, $n=325)$ milliseconds; with an interval between notes of 0.88-8.85 ( $\bar{x}=2.03 \pm 0.90, n=325) \mathrm{S}$. Amplitude modulation present in each note with beginning most intense and ending least intense; most notes weakly divided in two to three incomplete pulses with some notes single pulsed.

\section{Reproductive Behavior and Egg Deposition}

On 13 August 2004 at 19:30 h the adult female (TCWC 90337) and adult male (TCWC90335) were found amplectant in the axillary position on the outer leaf edges of the collected bromeliad under the mosquito netting. At 23:45 h they were no longer in amplexus. At 02:00 h on 14 August 2004, the pair was once again observed in amplexus. At $05: 45 \mathrm{~h}$ on 14 August 2004, the pair was no longer in amplexus and 17 white eggs were found clumped at the outer base of the bromeliad on the leaf litter and detritus buildup. Egg diameter was 3.2 to $3.7 \mathrm{~mm}(\overline{\mathrm{x}}=3.5 \pm 0.04, n=17)$.

\section{Discussion}

Sexual size dimorphism (SSD) has long been a characteristic observed in anurans, yet its biological significance remains poorly understood for many situations (Hayek and Heyer 2005). SSD in Eleutherodactylus is prominent throughout the genus, but few or no museum specimens exist for some sexes within a species (Lynch and Duellman 1997). Females were found to be significantly larger than males for the targeted morphometrics, further supporting the existence of SSD in the genus Eleutherodactylus. Morphometric data for anurans has also been a commonly used method for classifying species into groups, subgroups and assemblages (Heyer and Hardy 1991, Lynch and Duellman 1997, Guayasamin et al. 2006). A niche-specific association with bromeliads defines the E. lacrimosus assemblage along with morphological characters of a small body size and broad, flat, pointy head with the fifth toe much longer than third (Lynch and Ruíz-Carran- 

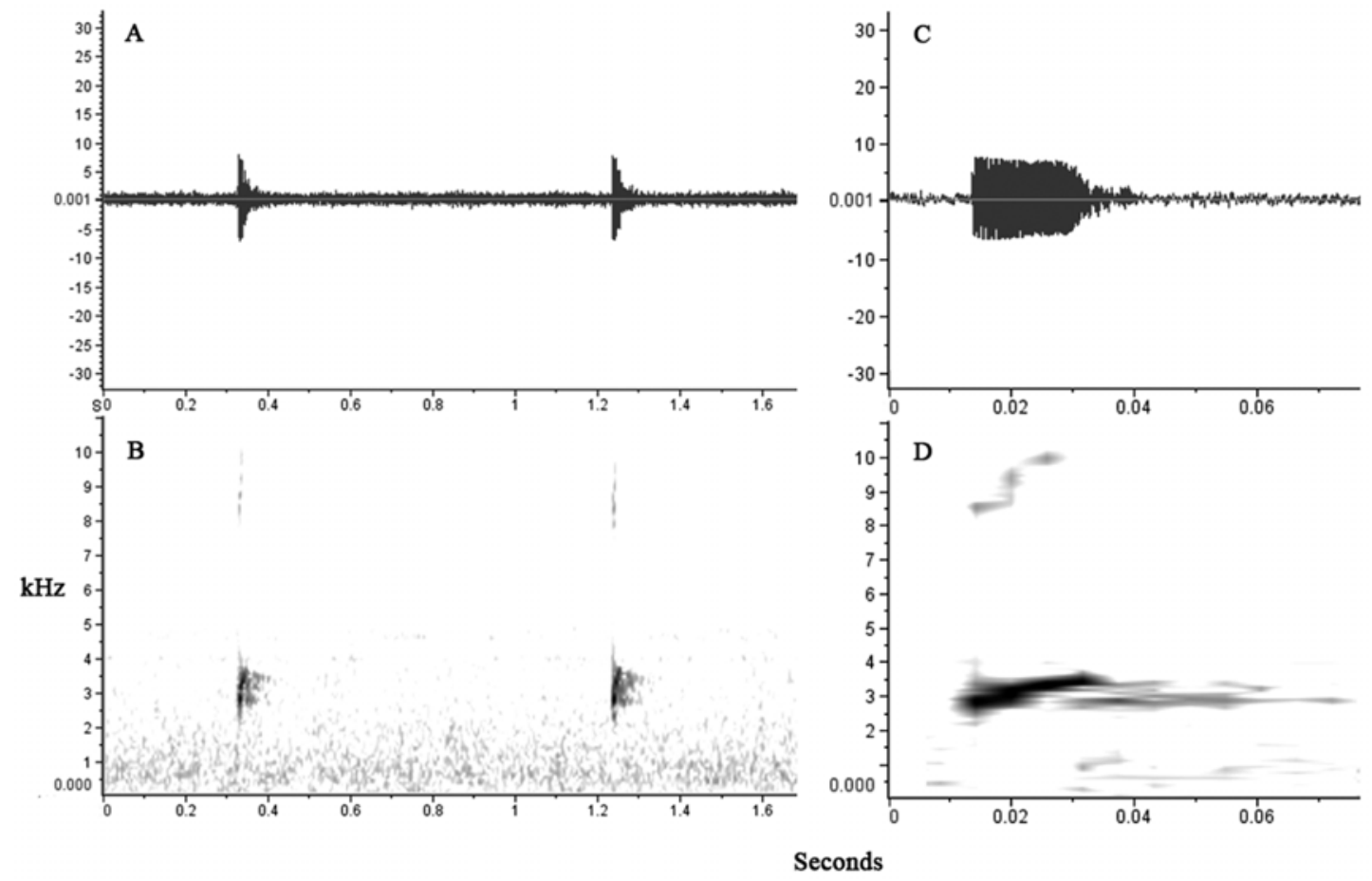

Figure 3 - Waveform (A) and spectrogram (B) of two consecutive calls of Eleutherodactylus aureolineatus. Waveform (C) and spectrogram (D) of a single call, showing greater detail of signal.

za 1985, Heyer and Hardy 1991, Guayasamin et al. 2006). Members of the E. unistrigatus species group are also characterized as not expressing SSD in tympanum diameter (Lynch and Duellman 1997). SSD for tympanum size was not significant in the analysis, reinforcing placement of E. aureolineatus in the E. unistrigatus species group.

Frogs of the genus Eleutherodactylus are primarily inhabitants of terrestrial and low $(<4$ m) arboreal microhabitats; a few species have been recorded in bromeliads up to $13 \mathrm{~m}$ (Lynch and Duellman 1997). Eleutherodactylus aureolineatus occupies bromeliads in the middle to upper strata of the rainforest canopy (19-50 m), with few individuals having been found on low vegetation $(\sim 1.5 \mathrm{~m})$ at night (Guayasamin et al. 2006). Ecological data for individuals $(n=14)$ shows collection occurred in bromeliads of two trees located in terra firme forest at upper elevations of the surveyed area, although bromeliads were sampled in only one tree (GMT4) located in a seasonally flooded stream plain during the authors sampling (Guayasamin et al. 2006). Eleutherodactylus aureolineatus has been found occupying the same bromeliad as Osteocephalus planiceps and Dendrobates ventrimaculatus (Guayasamin et al. 2006).

Advertisement calls for members of the $E$. lacrimosus assemblage have been noted for several species with only one having been recorded, Eleutherodactylus zimmermanae (Heyer and Hardy 1991). Heyer and Hardy (1991) proposed that recordings would help in establishing the ranges of species within the assemblage. In Guayasamin et al. (2006), E. aureolineatus was observed calling from a Ceiba tree over a leaf at night ca. $45 \mathrm{~m}$; we 
observed individuals calling from the outer edges of Aechmea zebrina leaves at night. Eleutherodactylus aureolineatus was observed calling on the evenings of cloudy or rainy days from May-August 2004. Eleutherodactylines typically deposit direct development eggs in terrestrial sites amongst leaf litter (Duellman 1978, Duellman and Trueb 1994). Egg deposition sites have only been reported for two species within the E. lacrimosus assemblage: $E$. tayrona eggs on bromeliad leaves in a single layer and E. zimmermanae on land (Lynch and Ruíz-Carranza 1985, IUCN 2004). Despite the dearth of information on egg deposition, our observation of eggs deposited at the base of a bromeliad was still surprising. This new deposition site within the E. lacrimosus assemblage may be linked to environmental factors of its arboreal habitat.

The lack of ecological and natural history data for the E. lacrimosus species assemblage may be particularly acute as a consequence of their predominant association with bromeliads. We provide data that may assist with further character delineation useful for those investigating the relationships of this group. The investigation described herein is beneficial in that it provides data and methods enabling researchers to identify parameters applicable for determining range and distributional patterns of the species. Furthermore, given the imperiled context of Ecuador's rainforests, having the highest deforestation rate in all of South America, these data provide a critical window on this poorly documented group of frogs and their important "wetlands in the sky". The continued implementation of canopy surveys and bromeliad patch sampling efforts is necessary to gather the data needed to further determine the relationships among the species within the assemblage.

\section{Acknowledgments}

Funding for this work was provided in part by the TADPOLE Organization, Austin, Texas,
USA in conjunction with private donors and Texas State University-Department of Biology. We thank all the staff at the Tiputini Biodiversity Station-Universidad San Francisco de Quito; especially Jaime Guerra, David Romo and Kelly Swing. David Romo for help obtaining research permit \# 006-IC-FA-PNY-RSO from the Ministerio del Ambiente, Ecuador. Consuelo de Romo for coordinating logistical support. Bejat McCracken for field work assistance and unwavering support. Paul Herbertson and Robert Winters for field work assistance. Mark Mulligan - King's College London for continued support. Floyd W. Weckerly, two anonymous reviewers and the editors for review, comments and suggestions used in the manuscript. 9

\section{References}

Duellman, W. E. 1978. The biology of an Equatorial herpetofauna in Amazonian Ecuador. Miscellaneous Publications of the University of Kansas Museum of Natural History 65: 1-352.

Duellman, W. E. and L. Trueb. 1994. Biology of Amphibians. Maryland. The John Hopkins University Press. $696 \mathrm{pp}$.

Fuentes, O. and C. L. Barrio-Amorós. 2004. A new Eleutherodactylus (Anura, Leptodactylidae) from Marahuake Tepui, Amazonas, Venezuela. Revista de la Academia Colombiana de Ciencias Exactas, Físicas y Naturales 28: 285-290.

Guayasamin, J. M. 2004. A new species of Eleutherodactylus (Anura: Leptodactylidae) from the northwestern lowlands of Ecuador. Herpetologica 60: 103-116.

Guayasamin, J. M., S. R. Ron, D. F. Cisneros-Heredia, W. Lamar, and S. F. McCracken. 2006. A new species of frog of the Eleutherodactylus lacrimosus assemblage (Leptodactylidae) from the western Amazon Basin, with comments on the utility of canopy surveys in lowland rainforest. Herpetologica 62: 191-202.

Hayek, L. C. and W. R. Heyer. 2005. Determining sexual dimorphism in frog measurement data: integration of statistical significance, measurement error, effect size and biological significance. Anais da Academia Brasileira de Ciências 77: 45-76.

Heyer, W. R. and L. M. Hardy. 1991. A new species of frog of the Eleutherodactylus lacrimosus assembly from Amazonia, South America (Amphibia: Anura: Leptodactylidae) from the northwestern lowlands of 
Ecuador. Proceedings of the Biological Society of Washington 104: 436-447.

IUCN, Conservation International and NatureServe. 2004. Global Amphibian Assessment. URL: http://www.globa lamphibians.org. Captured on 26 April 2006.

Kreft, H. and N. Köster. 2004. Vascular Epiphytes of the Yasuní - Color guide series. Chicago. Field Museum.

Lynch, J. D. and W. E. Duellman. 1980. The Eleutherodactylus of the Amazonian slopes of the Ecuadorian Andes (Anura: Leptodactylidae). Miscellaneous Publications of the University of Kansas Museum of Natural History 69: 1-86.

Lynch, J. D. and W. E. Duellman. 1997. Frogs of the genus Eleutherodactylus (Anura: Leptodactylidae) in western Ecuador: systematics, ecology, and biogeography. The
University of Kansas, Natural History Museum, Special Publication 23: 1-236.

Lynch, J. D. and P. M. Ruíz-Carranza. 1985. A synopsis of the frogs of the genus Eleutherodactylus from the Sierra Nevada de Santa Marta, Colombia. Occasional Papers of the Museum of Zoology, University of Michigan 711: 1-59.

Ribeiro, J. E. L. S., M. J. G. Hopkins, A. Vicentini, C. A. Sothers, M. A. S. Costa, J. M. Brito, M. A. D. Souza, L. H. P. Martins, L. G. Lohmann, P. A. C. L. Assunção, E. C. Pereira, C. F. Silva, M. R. Mesquita, and L. C. Procópio. 1999. Flora da Reserva Ducke: Guia de identificação das plantas vasculares de uma floresta de terra-firme na Amazônia Central. Manaus. Instituto Nacional de Pesquisas da Amazônia. 800 pp. 
Appendix I - Morphological measurements (in mm) for types, paratopotypes and paratypes of Eleutherodactylus aureolineatus (Guayasamin et al. 2006).

\begin{tabular}{|c|c|c|c|c|c|c|c|}
\hline Specimen & Sex & $\begin{array}{l}\text { Snout to Vent } \\
\text { Length }\end{array}$ & & $\begin{array}{c}\text { Tibia } \\
\text { Length }\end{array}$ & & $\begin{array}{l}\text { Head } \\
\text { Width }\end{array}$ & $\begin{array}{l}\text { Tympanum } \\
\text { Diameter }\end{array}$ \\
\hline TCWC 90337 & ㅇ & 28.6 & & 14.9 & & 12.2 & 1.5 \\
\hline TCWC 90340 & 우 & 26.3 & & 14.2 & & 11.2 & 1.4 \\
\hline TCWC 90342 & 우 & 26.4 & & 15.4 & & 11.0 & 1.4 \\
\hline QCAZ 19534 & 우 & 27.8 & & 14.8 & & 11.2 & 1.2 \\
\hline KU 220426 & 우 & 26.6 & & 13.5 & & 10.4 & 1.2 \\
\hline DFCH-USFQ 736 & 우 & 30.5 & & 14.9 & & 11.8 & 1.5 \\
\hline CRG 931 & 우 & 26.4 & & 13.8 & & 10.2 & 1.2 \\
\hline SUMMARY & 우우 & $\begin{array}{c}26.3-30.5 \\
\bar{x}=27.5 \pm 1.6\end{array}$ & $\bar{x}$ & $\begin{array}{l}13.5-15.4 \\
=14.5 \pm 0.7\end{array}$ & $\bar{x}$ & $\begin{array}{l}10.2-12.2 \\
=11.1 \pm 0.7\end{array}$ & $\begin{array}{c}1.2-1.5 \\
\bar{x}=1.3 \pm 0.1\end{array}$ \\
\hline TCWC 90335 & $\sigma^{x}$ & 21.3 & & 12.1 & & 8.7 & 1.3 \\
\hline TCWC 90338 & $\sigma^{x}$ & 26.1 & & 15.4 & & 10.6 & 1.3 \\
\hline TCWC 90339 & $\sigma^{\pi}$ & 28.8 & & 15.3 & & 12.0 & 1.5 \\
\hline QCAZ 20712 & $\sigma^{x}$ & 24.3 & & 12.9 & & 9.3 & 1.1 \\
\hline KU 106967 & $\sigma^{x}$ & 19.7 & & 11.5 & & 8.7 & 1.1 \\
\hline KU 148902 & $\sigma^{x}$ & 22.5 & & 11.5 & & 8.7 & 1.1 \\
\hline KU 148906 & $\sigma^{\pi}$ & 22.7 & & 11.9 & & 8.8 & 1.0 \\
\hline DFCH-USFQ 734 & $\sigma^{x}$ & 24.2 & & 12.2 & & 9.5 & 1.3 \\
\hline DFCH-USFQ 443 & $\sigma^{x}$ & 22.7 & & 12.7 & & 9.0 & 1.3 \\
\hline SUMMARY & $0^{x} 0^{x}$ & $\begin{array}{c}19.7-28.8 \\
\bar{x}=23.6 \pm 2.7\end{array}$ & $\bar{x}$ & $\begin{array}{l}11.5-15.4 \\
=12.8 \pm 1.5\end{array}$ & $\bar{x}$ & $\begin{array}{l}8.7-12.0 \\
=9.5 \pm 1.1\end{array}$ & $\begin{array}{c}1.0-1.5 \\
\bar{x}=1.2 \pm 0.2\end{array}$ \\
\hline
\end{tabular}

Appendix II - Vertical heights and environmental data collected for bromeliads with occurrences of Eleutherodactylus aureolineatus.

\begin{tabular}{lcccc}
\hline \multirow{2}{*}{ Environmental parameters } & \multicolumn{4}{c}{ Bromeliads } \\
\cline { 2 - 4 } & PMT5B1 & PMT5B4 & PMT6B1 & PMT6B2 \\
\hline Vertical height (m) & 38.0 & 35.5 & 23.5 & 23.5 \\
Water volume (L) & 1.240 & 1.654 & 1.050 & 1.195 \\
Temp. $\left({ }^{\circ} \mathrm{C}\right)$ @ 0 m & 24.5 & 24.5 & 23.8 & 23.8 \\
Temp. $\left({ }^{\circ} \mathrm{C}\right)$ @ 1 m & 25.0 & 25.0 & 24.0 & 24.0 \\
Temp. ( $\left.{ }^{\circ} \mathrm{C}\right)$ @ bromeliad & 24.0 & 24.0 & 23.0 & 23.0 \\
hPa @ 1 m & 1015 & 1014 & 1017 & 1017 \\
hPa @ bromeliad & 1015 & 1015 & 1014 & 1014 \\
\% relative humidity @ 1 m & 92.0 & 92.0 & 95.0 & 95.0 \\
Water pH & 5.45 & 4.97 & 5.30 & 4.88 \\
DBH of tree (cm) & 289.0 & 289.0 & 47.0 & 47.0 \\
\hline
\end{tabular}

